\title{
Credit Card Usage Pattern in Ozamiz City, Philippines
}

\author{
Ringgold P. Atienza \\ College of Business and Management, Misamis University, Ozamiz City, Philippines \\ Corresponding author: Ringgold P. Atienza, email: ringgoldatienza@yahoo.com
}

\begin{abstract}
The credit card market in the Philippines is growing and the household sector's increasing access to it could raise concern over how households might use the credit cards given the negative consequences associated with its misuse. This study examined the credit card usage pattern in Ozamiz City in terms of types of commodities purchased through credit cards and card ownership and determined how this pattern is influenced by the user's socioeconomic status and attitude towards debt. Survey method was used. The data were analyzed using the independent t-test and Pearson's correlation coefficient. Results showed that the type of commodities purchased with credit card is influenced by age, gender, marital status, educational attainment and income level but not with the number of dependents and the type of workplace organization. The credit card ownership is influenced by age, marital status, educational attainment and workplace organization but not the gender, number of dependents and income level. Findings also showed that cardholders with the positive attitude towards credit cards were less cautious of their credit card activities; thus, they were more susceptible to riskier activities than those cardholders with the negative attitude towards debt. Overall results showed that the credit card usage pattern varies among different context. Results of this study can help issuing banks for more effective regulation on credit and collection, as well as organizations that promote financial education for consumer protection.
\end{abstract}

Keywords: cardholders, commodities, debt, financial, income 


\section{Introduction}

In the past 25 years, credit card has become almost universallyheld product as shown by an increase in credit card ownership from $4 \%$ to 77\% (Johnson, 2007). Credit card ownership and usage have substantially increased in recent decades (Wickramasinghe \& Gurugamage, 2009). Credit card ownership is so widespread among consumers in some of the rich and economically developed countries that penetration rates are approaching $100 \%$. Credit cards are similarly becoming increasingly available in many parts of developing countries (Abdul-Muhmin \& Umar, 2007).

In Asia, the liberalization of the financial sectors has resulted in the rapid proliferation of credit card companies (Gan et al., 2008). In the Philippines, credit cards provided by the banking industry are an emerging source of household credit (Tan, 2009). The credit card outstanding loans in the country grew to Php 190.55 billion at the end of the year 2013, with an average annual increase of $7.89 \%$ from 2008 (Banko Sentral ng Pilipinas [BSP], 2014a). This trend reflects the growing popularity of the credit card as a preferred mode of payment for goods and services in lieu of cash, checks, and other forms of payment (Abdul-Muhmin \& Umar, 2007).

Using credit cards as a substitute for cash has benefits such as convenience in paying goods or services, immediate source of financing and facility for online purchasing. Consumption becomes easier since individuals do not have to go to automated teller machines very frequently to withdraw cash nor do they have to carry a lot of cash; both actions could reduce the risk of theft (Cayanan \& Ledesma, 2005). However, the misuse and abuse of using credit cards can have many negative consequences, ranging from spending beyond what the budget allows to paying high interest rates on past due accounts on the part of consumers. On the part of the credit card providers, defaults on consumer payments may ensue. Among the specific negative impacts of credit card misuse on the part of the cardholder are the penalties applied for failure to live up to the terms of use (Joo et al., 2003), years of financial debt resulting to low credit scores, personal bankruptcy (Holub, 2002; Roberts \& Jones, 2001), and increased level of stress that could cause a decreased level of psychological well-being (Norvilitis \& Santa Maria, 2002; Roberts \& 
Jones, 2001). A more devastating impact is that high levels of debt have been reported as major stressors that have led credit card users to commit suicide (Holub, 2002; Roberts \& Jones, 2001).

In the Philippines, the rate of consumer defaults almost triples the average in Asia (Estayo, 2008). For the last five years, the average non-performing loans or past due accounts amount to Php18.02 billion. Defaults of payment among cardholders could lead to higher credit expense due to compounding interests and penalties. Worsening the problem, the credit card interest rates in the country are currently among the highest in the world (Tan, 2009). On average, consumers end up paying $3.5 \%$ interest rate per month or $42 \%$ per annum on past due accounts while the average lending rate of commercial banks only ranges from $6.21 \%$ per annum in the start of first-quarter of 2013 to $5.72 \%$ per annum at the end of the forth-quarter of 2013 (BSP, 2014a). The high-interest margin is imposed by banks on credit cards because credit risk is inherent in the industry; credit card transactions do not require collateral and high transaction costs can be incurred if banks go to court in the case of defaults (Cayanan \& Ledesma, 2005). Therefore, the credit card industry becomes problematic if credit cards are given to the consumers who do risky credit card activities. Despite the situation, there is still an immense marketing campaign among credit card issuers in the country. The increase in credit card usage among consumers is due to the developing nature of the financial system in the country (BSP, 2014b).

Lee and Kwon (2002) reported that credit cardholders have different motives in owning a credit card and so they differ in their payment practice. The authors categorized the cardholders into two types based on the mode of payment that they practice: the convenience users and the revolvers. Convenience users tend to use credit cards as an easy mode of payment and pay their balance typically in full on or before the due date stated in the account statement. Revolvers, on the other hand, use the card principally as a mode of financing and elect to pay interest charges on the unpaid balance. The credit card interest rate on past due accounts in the Philippines is very high causing the revolvers to incur higher cost of financing compared to any other form of credit facility; as such, defaulting on credit card payments is not an advisable path to take.

Credit cardholders differ in their attitude towards credit cards. Davies and Lea (1995) categorized the attitude of cardholders towards 
credit cards as positive and negative by examining the relationship between attitude and credit. Their study showed that individuals adopted a more positive attitude as their credit increased due to low income and high expenses. Those who have positive attitude towards credit cards are the ones who like to own or maximize the use of credit cards while those who have negative attitude towards credit cards are the ones who avoid or minimize the use of credit cards (Borden et al., 2008). It was noted that positive credit card attitude elicits credit card spending and risky activities (Borden et al., 2008; Hayhoe et al., 2000; Xiao, 1995; Danes \& Hira, 1990).

Many studies have been conducted on credit card usage behavior. These are largely undertaken in the middle and high-income countries such as India, USA, Malaysia, Singapore, Saudi Arabia, China, Turkey, London and Hongkong (Khare et al., 2012; Hancock et al., 2013; Wang et al., 2011; Gan et al., 2008; Abdul-Muhmin \& Umar, 2007; Ramayah et al., 2002; Sharpe et al., 2012; Kaynak \& Harcar, 2001; Hamilton \& Khan, 2001; Chan, 1997). These studies indicate that the credit card usage pattern of consumers, which includes the type of commodities paid through credit card, number of credit cards owned, frequency of usage, monthly credit card expense, payment practice and attitude towards credit card, is influenced by the socioeconomic status of the cardholders. Low-income countries, particularly Botswana and Sri Lanka, have little research attention (Themba \& Tumedi, 2012; Wickramasinghe \& Gurugamage, 2009).

Meanwhile, studies that have been conducted on the influence of socioeconomic status to the type of spending using credit cards showed that the latter is influenced by the cardholders' age, gender, income level, marital status, and educational attainment (Wickramasinghe \& Gurugamage, 2009; Kaynak \& Harcar, 2001; Barker \& Sekerkaya, 1992). Studies have also been conducted on the influence of socioeconomic status on the number of credit card ownership and the attitude of cardholders in owning credit card. These studies examined various variables including income level, gender, age, educational attainment and marital status but did not include the type of workplace and number of dependents of cardholders; these last two variables are included in this study. Conflicting results have been found in the reviewed literature on how the credit card usage pattern is influenced by the socioeconomic status of cardholders. 
For example, Choi and DeVaney (1995) reported that credit card ownership was not influenced by income level while studies of Danes and Hira (1990), Sharpe et al. (2012), Themba and Tumedi (2012), Abdul-Muhmin and Umar (2007), Kaynak and Harcar (2001), Chan (1997), Heck (1987) and Adcock (1977) found that income level was influential.

Exploring the credit card usage pattern in the context of a middleincome country such as the Philippines is important considering the country's situation in its rate of credit default. Among the three cities in the province of Misamis Occidental, Ozamiz City is regarded as the center of commerce, health, transportation and education. Its financial industry is booming as evidenced by the existence of 25 financial institutions of different types, ranging from commercial banks to cooperatives. Credit cards are heavily marketed to many individuals. The same trend in other cities posed a problem in an increase of credit defaults which are caused by the lax credit card policy and the lack of financial literacy among cardholders (Ludlum et al., 2012). Hence, determining the patterns of risky activities among cardholders in this area can help the banking industry formulate a more effective and efficient regulation on credit and collection. On the part of the government and organizations that promote financial literacy among credit cardholders, knowledge from this study is important for consumer protection on credit cards (Finke \& Huston, 2014).

This study aimed to examine the credit card usage pattern in Ozamiz City and how it is influenced by the users' socioeconomic status and attitude towards debt. Specifically, this study determined the socioeconomic characteristics of cardholders such as age, gender, marital status, number of dependents, educational attainment, type of workplace, income and how these variables influenced the type of commodities paid through credit cards and the number of credit card owned. It also examined the relationship between the number of credit cards owned and attitude towards credit cards.

\section{Materials and Methods}

This study was conducted in Ozamiz City, Philippines. A researcher-made survey questionnaire was developed through the insights gained from related studies in Saudi Arabia, Sri Lanka, Singapore, 
and USA (Abdul-Muhmin \& Umar, 2007; Wickramasinghe \& Gurugamage, 2009; Gan et al., 2008; Hancock et al., 2013). An initial interview of the credit cardholders in the locale of the study was also done to develop a survey questionnaire that is applicable to the Philippine context. The survey questionnaire consisted of three parts. The first part was for the socioeconomic characteristics which included the age, gender, marital status, number of dependents, educational attainment, workplace organization, and income of the respondents. The second part was for the number of credit cards owned and usage that included the commodities purchased through credit card, frequency of credit card use, monthly credit card expenses, monthly credit card payment and, late or missed payments. The commodities purchased through credit cards, which consisted of 16 categories, were measured using the four-point Likert scale that ranges from (1) 'never' to (4) 'most of the time'. The third part consisted of 11 items that measured the respondent's attitude towards credit card using the four-point Likert scale ranging from (1) 'strongly disagree' to (4) 'strongly agree'. Cronbach's alpha was run on a sample size of 50 to estimate the reliability of the 11 items of the third part of the questionnaire. The test resulted to a value of .845 which suggests that the items were highly reliable in measuring the respondent's attitude towards credit card (Nolan \& Heinzen, 2010).

Using the drop-off/pick-up method of questionnaire administration (Zikmund, 2003), survey questionnaires were personally distributed to and retrieved from the different government institutions, private institutions and households in the locale of the study. Respondents were asked first whether they owned a credit card and the informed consent was sought prior to the conduct of the survey. A total of 215 questionnaires, comprising of $59 \%$ of those distributed, were retrieved and analyzed.

The independent t-test was used to determine if the commodities paid through credit cards, number of credit cards owned and attitude towards debt differ significantly according to the socioeconomic status of credit cardholders. Independent t-test is used when comparing two means for a between-groups research design (Nolan \& Heinzen, 2010). In order to achieve this test, the socioeconomic status variables were recorded into two levels: age was recorded as older (for respondents 36 years old and above) and younger (for respondents 35 years old and below); gender as men and women; marital status as single and married; number of 
dependents as more dependents (3 and above) and less dependents ( 2 and below); educational attainment as master's degree and doctorate degree, and high school and college degree; workplace organization as private and public; and income as higher income group (30,000 above) and lower income group (30,000 and below). The Pearson's correlation coefficient was used to measure the linearity of the attitude towards credit card and the credit card ownership (Nolan \& Heinzen, 2010). The SPSS (Statistical Package for Social Sciences) was used as a tool in performing data analysis.

\section{Results and Discussion}

Table 1 shows the socioeconomic profile of the respondents. Older cardholders comprised $50.2 \%$ of the respondents. There were more female credit cardholders than the males. Majority are married, no dependents and at least college degree holders. Credit cardholders composed of workers in public and private institutions. On average, the respondents had personal monthly income of around Php 20,000 to Php 30,000.

Table 1. Socioeconomic profile of the respondents $(n=215)$.

\begin{tabular}{|c|c|c|c|c|c|}
\hline $\begin{array}{l}\text { Socioeconomic } \\
\text { characteristics }\end{array}$ & Frequency & $\%$ & $\begin{array}{l}\text { Socioeconomic } \\
\text { characteristics }\end{array}$ & Frequency & $\%$ \\
\hline Age & & & Educational attainment & & \\
\hline 25 or below & 25 & 12 & High School & 6 & 3 \\
\hline $26-35$ & 82 & 38 & College Degree & 140 & 65 \\
\hline $36-45$ & 69 & 32 & Master's Degree & 61 & 28 \\
\hline 46 or above & 39 & 18 & Doctorate Degree & 8 & 4 \\
\hline Gender & & & Workplace organization & & \\
\hline Men & 73 & 34 & Private & 86 & 40 \\
\hline Women & 142 & 66 & Public & 129 & 60 \\
\hline Marital status & & & Personal Monthly Income (Php) & & \\
\hline Single & 57 & 27 & Less than 10,000 & 21 & 10 \\
\hline Married & 158 & 73 & $10,000-19,999$ & 90 & 42 \\
\hline Number of & & & $20,000-29,999$ & 64 & 30 \\
\hline dependents & & & $30,000-39,999$ & 30 & 14 \\
\hline None & 92 & 43 & $40,000-49,999$ & 3 & 1 \\
\hline 1 & 45 & 21 & 50,000 and above & 7 & 3 \\
\hline 2 & 48 & 22 & & & \\
\hline 3 & 16 & 7 & & & \\
\hline 4 & 10 & 5 & & & \\
\hline 5 & 4 & 2 & & & \\
\hline
\end{tabular}


Figure 1 shows the types of commodities purchased through credit cards. The most frequent spending made with credit cards was on food. Thereby, food shared the biggest proportion of the credit card expenditure of an individual or in a household. In addition, clothing, travel, households and gadgets were among the top commodities purchased using credit cards. Internet, entertainment and books were among the least commodities purchased using credit cards.

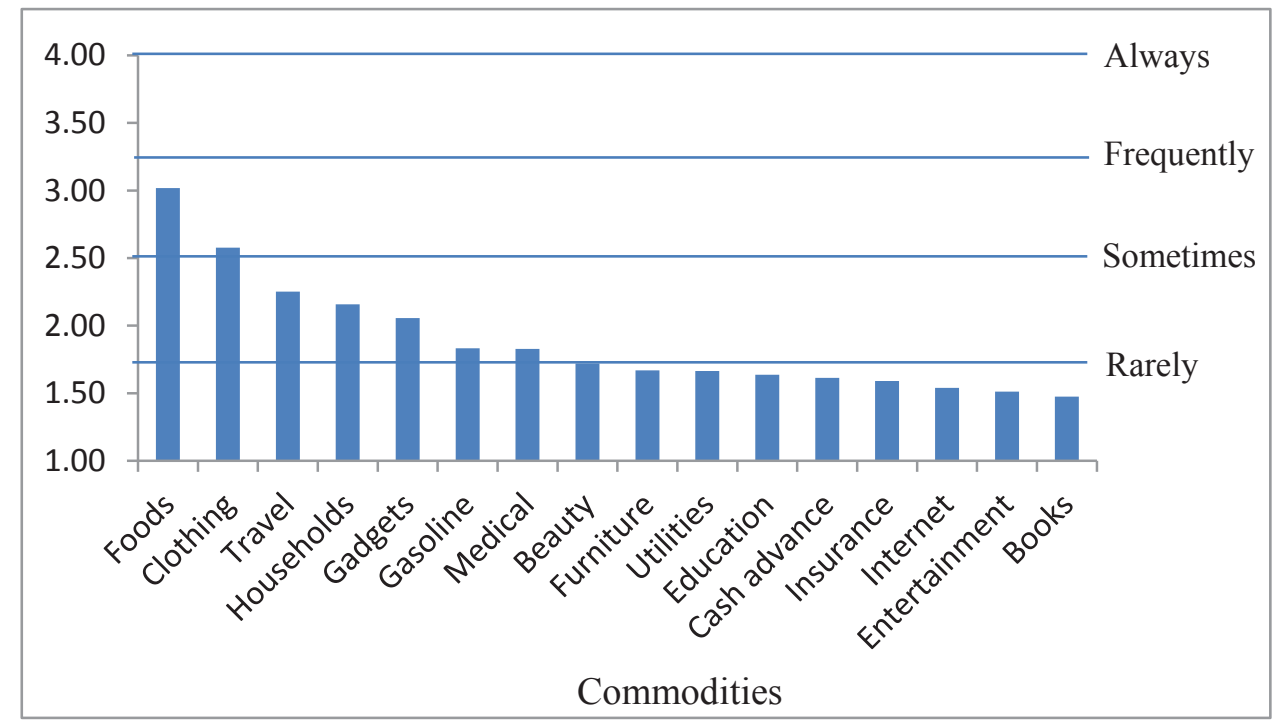

$\begin{aligned} \text { Legend: } 1.00-1.75 & \text { Rarely } \\ 1.76-2.50 & \text { Sometimes } \\ 2.56-3.25 & \text { Frequently } \\ 3.26-4.00 & \text { Always }\end{aligned}$

Figure 1. Commodities purchased through credit cards.

In this study, the commodities purchased through credit cards varied among young and old cardholders. Credit cards among older cardholders (36 and above) were frequently used for gasoline, education and cash advances as shown in the results of the independent t-test (Table 2). This study also revealed that it was only paying the internet through credit cards which showed significance towards younger cardholders. The younger generation is more exposed to the internet and more confident doing transactions online than the old cardholders. The 
other types of commodities were shown to have not been influenced by age. The results of the study differed from a study done in Sri Lanka (Wickramasinghe \& Gurugamage, 2009) which found that the younger cardholders spent more on durable items like furniture and gadgets.

Table 2. Independent t-test on credit card usage pattern by age.

\begin{tabular}{lccc}
\hline \hline Credit Card Usage Pattern & \multicolumn{2}{c}{ Age } & df = 213 \\
Older (n=108) & Younger (n=107) & Sig. (two-tailed) \\
\hline Types of commodities & & & \\
Food & 3.05 & 2.99 & .713 \\
Clothing & 2.50 & 2.65 & .211 \\
Travel & 2.17 & 2.34 & .243 \\
Household & 2.24 & 2.07 & .291 \\
Gadgets & 1.97 & 2.14 & .231 \\
Gasoline & 2.00 & 1.66 & $.021^{*}$ \\
Medical & 1.90 & 1.76 & .314 \\
Beauty Products & 1.72 & 1.72 & .982 \\
Furniture & 1.62 & 1.72 & .376 \\
Utilities & 1.56 & 1.78 & .070 \\
Education & 1.82 & 1.45 & $.008^{*}$ \\
Cash Advance & 1.77 & 1.46 & $.012^{*}$ \\
Insurance & 1.70 & 1.48 & .091 \\
Internet & 1.29 & 1.79 & $.000^{*}$ \\
Entertainment & 1.51 & 1.51 & .965 \\
Books & 1.52 & 1.43 & .401 \\
Credit card ownership and attitude towards credit card & & $.060^{*}$ \\
Number of credit cards owned & 1.81 & 1.82 & .331 \\
Frequency of usage & 2.74 & 2.83 & .397 \\
Monthly credit card expense & 2.18 & 1.76 & $.020^{*}$ \\
Tendency to revolve & 2.04 & 1.80 & $.033^{*}$ \\
Missed payments & 2.24 & 1.75 & .006 \\
Attitude towards credit card & 2.69 & 2.63 & \\
\hline \hline
\end{tabular}

*Significant at $p<0.05$ 
On credit card ownership, the young and old cardholders did not differ in terms of the number of credit cards owned and the frequency of usage. This result is inconsistent with several studies from Botswana (Themba \& Tumedi, 2012), Saudi Arabia (Abdul-Muhmin \& Umar, 2007), Singpore (Ramayah et al., 2002), Istanbul (Kaynak \& Harcar, 2001), Hongkong (Chan, 1997) and USA (Heck, 1987; Adcock et al., 1977) which showed that the older cardholders owned more credit cards and used them more frequently.

Older cardholders incurred higher credit card expense, tended to become revolvers and often missed payments than the younger cardholders. The findings are consistent with the results from Botswana (Themba \& Tumedi, 2012), Singapore (Ramayah et al., 2002) and USA (Hamilton \& Khan, 2001). Sharpe et al. (2012), in a study conducted in China, explained further that older cardholders had less awareness of the consequences of defaulting on payments. In contrast, a study from India (Khare et al., 2012) showed that younger cardholders were the ones who had the tendency to revolve while the findings from Saudi Arabia (Abdul-Muhmin \& Umar, 2007) showed that age was not an influential variable when it came to determining the tendency to revolve. This study also revealed that age influenced the attitude of the credit cardholders towards credit card.

In this study, gender difference was present in some types of commodities purchased through credit cards. Women cardholders spent more on food and beauty products while men cardholders spent more on insurance as shown in the results of the independent t-test (Table 3). The other types of commodities were not influenced by gender. The findings of other studies from Sri Lanka and Istanbul showed that women used credit cards to purchase more frequently on medical expenses, household goods, clothing and personal belongings while men used them for payment for electronics, entertainment, travel and food (Wickramasinghe \& Gurugamage, 2009; Kaynak \& Harcar, 2001).

Although gender difference was reflected in the types of commodities purchased through credit cards, no difference in credit card ownership and in the attitude towards credit card was captured. It could mean that attitude does not necessarily predict behavior (Chien \& DeVaney, 2001). 
Table 3. Independent t-test on credit card usage pattern by gender.

\begin{tabular}{lccc}
\hline \hline \multirow{2}{*}{ Credit Card Usage Pattern } & \multicolumn{2}{c}{ Gender } & df = 213 \\
& Men (n=73) & Women (n=142) & Sig. (two-tailed) \\
\hline Types of commodities & & & \\
Food & 2.78 & 3.14 & $.032^{*}$ \\
Clothing & 2.66 & 2.54 & .348 \\
Travel & 2.26 & 2.25 & .929 \\
Household & 1.99 & 2.25 & .104 \\
Gadgets & 2.07 & 2.05 & .897 \\
Gasoline & 1.82 & 1.84 & .917 \\
Medical & 1.70 & 1.89 & .185 \\
Beauty Products & 1.44 & 1.87 & $.000^{*}$ \\
Furniture & 1.64 & 1.68 & .740 \\
Utilities & 1.68 & 1.65 & .816 \\
Education & 1.75 & 1.58 & .239 \\
Cash advance & 1.62 & 1.61 & .977 \\
Insurance & 1.81 & 1.48 & $.034 *$ \\
Internet & 1.58 & 1.52 & .679 \\
Entertainment & 1.51 & 1.51 & .949 \\
Books & 1.44 & 1.49 & .625 \\
Credit card ownership and attitude towards credit card & & .722 \\
Number of credit cards owned & 1.78 & 1.84 & .664 \\
Frequency of usage & 2.75 & 2.80 & .825 \\
Monthly credit card expense & 1.99 & 1.96 & .370 \\
Tendency to revolve & 2.01 & 1.87 & .95 \\
Missed payments & 2.08 & 2.64 & \\
Attitude towards credit card & 2.69 & & .74 \\
\hline \hline
\end{tabular}

*Significant at $p<0.05$

Many studies conducted in other countries such as India, Saudi Arabia, Istanbul, Hongkong, and USA showed that men are more likely to own credit cards and have the tendency to become revolvers than women (Khare et al., 2012; Abdul-Muhmin \& Umar, 2007; Kaynak \& Harcar, 2001; Chan, 1997; Heck, 1987; Adcock et al., 1977). Some studies from Botswana, USA and Singapore showed that women are more likely to have more credit cards, used their credit card frequently, spent more on credit card, tended to revolve and engaged more likely in risky credit card activities than men (Themba \& Tumedi, 2012; Hancock et al., 2013; Robb, 2011; Lyons, 2004; Gan et al., 2008; Arora, 1987; Kinsey, 1981). Furthermore, it is explained in the study from Sri Lanka that women pay 
more attention to debt ceiling in choosing a credit card than men (Wickramasinghe \& Gurugamage, 2009). Among the men and women respondents of the current study, these differences were not found to be present.

It can be seen from Table 4 that married cardholders spend more on gasoline, medical expense, education and cash advances through credit cards while single cardholders spend more on internet services. A study from Sri Lanka showed that single cardholders spent more on entertainment (Wickramasinghe \& Gurugamage, 2009), a finding not captured in the current study. Other expenditures were also not influenced by marital status in this study.

Table 4. Independent t-test on credit card usage pattern by marital status.

\begin{tabular}{lccc}
\hline \hline \multirow{2}{*}{ Credit Card Usage Pattern } & \multicolumn{2}{c}{ Marital Status } & df $=\mathbf{2 1 3}$ \\
& Married $(\mathbf{n}=\mathbf{1 5 8})$ & Single (n=57) & Sig. (two-tailed) \\
\hline Types of commodities & 3.06 & 2.91 & .399 \\
Food & 2.52 & 2.74 & .076 \\
Clothing & 2.26 & 2.23 & .849 \\
Travel & 2.21 & 2.02 & .260 \\
Household & 2.01 & 2.19 & .240 \\
Gadgets & 1.96 & 1.49 & $.003^{*}$ \\
Gasoline & 1.91 & 1.60 & $.029^{*}$ \\
Medical & 1.72 & 1.74 & .871 \\
Beauty & 1.68 & 1.63 & .682 \\
Furniture & 1.66 & 1.67 & .988 \\
Utilities & 1.73 & 1.39 & $.017^{*}$ \\
Education & 1.70 & 1.39 & $.016^{*}$ \\
Cash advance & 1.61 & 1.54 & .677 \\
Insurance & 1.41 & 1.89 & $.003^{*}$ \\
Internet & 1.49 & 1.56 & .578 \\
Entertainment & 1.47 & 1.49 & .848 \\
Books & 1.84 & & .713 \\
Credit card ownership and attitude towards credit card & 1.77 & .060 \\
Number of credit cards owned & 2.73 & 2.93 & $.000^{*}$ \\
Frequency of usage & 2.15 & 1.47 & $.043^{*}$ \\
Monthly credit card expense & 1.99 & 1.74 & $.000^{*}$ \\
Tendency to revolve & 2.16 & 1.54 & .957 \\
Missed payments & 2.66 & 2.66 & \\
Attitude towards credit card & & & \\
\hline \hline
\end{tabular}

*Significant at $p<0.05$ 
With respect to credit card ownership, the findings of this study revealed that marital status did not also influence the number of credit cards owned and the frequency of usage as shown in the result of independent t-test. These findings are not consistent with the studies from Malaysia and USA which showed that married cardholders have more credit cards (Ramayah et al., 2002; Delener \& Katzenstein, 1994). In the study conducted in Istanbul (Kaynak \& Harcar, 2001), singles used credit cards more frequently.

This study also revealed that married cardholders incurred higher credit card expense, tended to become revolvers and often missed payments than single cardholders. These findings are consistent with the study from Botswana (Themba \& Tumedi, 2012). A study from India showed a different result wherein single cardholders tended to become revolvers (Khare et al., 2012).

It is also shown in the current study that single and married cardholders have a similar attitude towards credit card. This finding is not consistent with the study from Singapore (Gan et al., 2008) which shows that singles have a positive attitude towards credit card, and married people tend to be more wary of interest payment.

It is revealed in this study that having more or few dependents did not influence the type of commodities purchased through credit cards, credit card ownership and attitude towards credit card (Table 5). Cardholders with more dependents showed higher spending on education than cardholders with fewer dependents but the independent t-test did not show a significant difference at $p<0.05$.

As shown in Table 6, cardholders with high school and college education spent more on medical expenses using credit cards. Other expenditures were not influenced by educational attainment. This finding is not consistent with the study from Sri Lanka (Wickramasinghe \& Gurugamage, 2009) which showed that less educated cardholders spent more on entertainment while highly educated cardholders used their credit cards more to pay for utility bills and mortgages. 
Table 5. Independent t-test on credit card usage pattern by the number of dependents.

\begin{tabular}{lccc}
\hline \hline Credit Card Usage Pattern & \multicolumn{2}{c}{ Number of Dependents } & df = 213 \\
& More (n=158) & Fewer (n=57) & Sig.(two-tailed) \\
\hline Types of commodities & & & \\
Food & 3.17 & 2.99 & .431 \\
Clothing & 2.40 & 2.61 & .249 \\
Travel & 2.10 & 2.28 & .366 \\
Household & 2.40 & 2.12 & .215 \\
Gadgets & 2.20 & 2.03 & .408 \\
Gasoline & 1.97 & 1.81 & .460 \\
Medical & 1.87 & 1.82 & .811 \\
Beauty Products & 1.90 & 1.69 & .312 \\
Furniture & 1.60 & 1.68 & .616 \\
Utilities & 1.63 & 1.67 & .834 \\
Education & 2.03 & 1.57 & .057 \\
Cash advance & 1.80 & 1.58 & .230 \\
Insurance & 1.60 & 1.59 & .956 \\
Internet & 1.37 & 1.57 & .158 \\
Entertainment & 1.67 & 1.49 & .317 \\
Books & 1.57 & 1.46 & .482 \\
Credit card ownership and attitude towards credit card & & .062 \\
Number of credit cards owned & 1.47 & 1.88 & .371 \\
Frequency of usage & 2.67 & 2.81 & .117 \\
Monthly credit card expense & 2.43 & 1.89 & .188 \\
Tendency to revolve & 2.10 & 1.89 & .575 \\
Missed payments & 2.27 & 1.95 & \\
Attitude towards credit card & 2.70 & 2.65 & \\
\hline \hline
\end{tabular}

*Significant at $p<0.05$

This study showed that the educational attainment of a credit cardholder did not influence credit card ownership. However, other literature revealed otherwise. Highly educated cardholders owned more credit cards, used credit cards more frequently and spent more using credit cards (Themba \& Tumedi, 2012; Sharpe et al., 2012; Abdul-Muhmin \& Umar, 2007; Kaynak \& Harcar, 2001; Chan, 1997; Canner et al., 1992; Danes \& Hira, 1990; Heck, 1987; Adcock et al., 1977). The study from Saudi Arabia (Abdul-Muhmin \& Umar, 2007) and India (Khare et al., 2012) showed that highly educated cardholders are less likely to revolve but the study from Botswana (Themba \& Tumedi, 2012) showed 
otherwise. However, it is revealed in this study that cardholders with high school and college education have higher positive attitude than the cardholders with masters and doctorate education. The result makes sense since as an individual becomes more educated, one becomes more knowledgeable and wary of his credit standing and finances.

Table 6. Independent t-test on credit card usage pattern by the level of educational attainment.

\begin{tabular}{|c|c|c|c|}
\hline \multirow[b]{2}{*}{ Credit Card Usage Pattern } & \multicolumn{2}{|c|}{ Educational Attainment } & \multirow{2}{*}{$\begin{array}{c}d f=213 \\
\text { Sig.(two-tailed) }\end{array}$} \\
\hline & $\begin{array}{c}\text { MA/MS/Ph.D. } \\
\quad(n=69)\end{array}$ & $\begin{array}{c}\text { HS/College } \\
(n=146)\end{array}$ & \\
\hline \multicolumn{4}{|l|}{ Types of commodities } \\
\hline Food & 2.94 & 3.05 & .487 \\
\hline Clothing & 2.46 & 2.63 & .208 \\
\hline Travel & 2.26 & 2.25 & .927 \\
\hline Household & 2.36 & 2.06 & .073 \\
\hline Gadgets & 2.10 & 2.03 & .655 \\
\hline Gasoline & 1.77 & 1.86 & .544 \\
\hline Medical & 1.62 & 1.92 & $.044 *$ \\
\hline Beauty Products & 1.80 & 1.68 & .372 \\
\hline Furniture & 1.70 & 1.66 & .751 \\
\hline Utilities & 1.65 & 1.67 & .884 \\
\hline Education & 1.45 & 1.73 & .067 \\
\hline Cash advance & 1.70 & 1.58 & .369 \\
\hline Insurance & 1.55 & 1.61 & .684 \\
\hline Internet & 1.67 & 1.48 & .207 \\
\hline Entertainment & 1.59 & 1.47 & .290 \\
\hline Books & 1.51 & 1.46 & .669 \\
\hline \multicolumn{4}{|c|}{ Credit card ownership and attitude towards credit card } \\
\hline Number of credit cards owned & 1.87 & 1.79 & .646 \\
\hline Frequency of usage & 2.93 & 2.72 & .069 \\
\hline Monthly credit card expense & 2.04 & 1.93 & .593 \\
\hline Tendency to revolve & 1.84 & 1.96 & .314 \\
\hline Missed payments & 1.91 & 2.03 & .416 \\
\hline Attitude towards credit card & 2.55 & 2.71 & $.010^{*}$ \\
\hline
\end{tabular}

*Significant at $p<0.05$

Credit cardholders in private and public institutions did not differ in terms of their type of commodities purchased through credit cards (Table 7). On the credit card ownership, results showed that public and 
private workers did not differ in the number of credit cards owned and their tendency to revolve. However, results pointed out that public workers used credit cards more frequently. On the other hand, private workers spent more and missed their payments more frequently. Private workers also have more positive attitude towards credit card.

Table 7. Independent t-test on credit card usage pattern by the type of workplace organization.

\begin{tabular}{lccc}
\hline \hline \multirow{2}{*}{ Credit Card Usage Pattern } & \multicolumn{2}{c}{ Workplace Organization } & df = 213 \\
& Public (n=129) & Private (n=86) & Sig. two-tailed \\
\hline Types of commodities & 3.05 & & \\
Food & 2.53 & 2.97 & .564 \\
Clothing & 2.25 & 2.64 & .406 \\
Travel & 2.21 & 2.26 & .958 \\
Household & 2.09 & 2.08 & .425 \\
Gadgets & 1.74 & 2.00 & .516 \\
Gasoline & 1.78 & 1.97 & .138 \\
Medical & 1.73 & 1.91 & .357 \\
Beauty Products & 1.64 & 1.71 & .871 \\
Furniture & 1.71 & 1.71 & .565 \\
Utilities & 1.53 & 1.60 & .418 \\
Education & 1.51 & 1.79 & .076 \\
Cash advance & 1.54 & 1.77 & .054 \\
Insurance & 1.63 & 1.66 & .383 \\
Internet & 1.57 & 1.41 & .069 \\
Entertainment & 1.41 & 1.42 & .139 \\
Books & 1.88 & 1.57 & .140 \\
Credit card ownership and attitude towards credit card & & $.034^{*}$ \\
Number of credit cards owned & 2.88 & 1.72 & .295 \\
Frequency of usage & 1.70 & 2.64 & $.025^{*}$ \\
Monthly credit card expense & 1.88 & 2.37 & $.001^{*}$ \\
Tendency to revolve & 1.80 & 1.98 & .406 \\
Missed payments & 2.61 & 2.29 & $.001^{*}$ \\
Attitude towards credit card & & 2.74 & .03 \\
\hline \hline
\end{tabular}

*Significant at $p<0.05$ 
High-income credit cardholders spent more on books than those from the lower income group (Table 8). Purchases on other types of commodities were not influenced by income level. Studies from developing countries showed that high-income cardholders spent more on different product categories (Kaynak \& Harcar, 2001; Barker \& Sekerkaya, 1992).

Table 8. Independent t-test on credit card usage pattern by income level.

\begin{tabular}{lccc}
\hline \hline Credit Card Usage Pattern & \multicolumn{2}{c}{ Income Level } & df $=\mathbf{2 1 3}$ \\
& High $(\mathbf{n = 4 0})$ & Low (n=175) & Sig. (two-tailed) \\
\hline Types of commodities & 2.88 & 3.05 & .404 \\
Food & 2.58 & 2.58 & .989 \\
Clothing & 2.48 & 2.20 & .141 \\
Travel & 2.30 & 2.13 & .388 \\
Household & 2.28 & 2.01 & .191 \\
Gadgets & 2.08 & 1.78 & .112 \\
Gasoline & 1.88 & 1.82 & .748 \\
Medical & 1.83 & 1.70 & .396 \\
Beauty Products & 1.88 & 1.62 & .079 \\
Furniture & 1.83 & 1.63 & .209 \\
Utilities & 1.63 & 1.64 & .934 \\
Education & 1.85 & 1.56 & .070 \\
Cash advance & 1.93 & 1.51 & .052 \\
Insurance & 1.53 & 1.54 & .911 \\
Internet & 1.58 & 1.50 & .572 \\
Entertainment & 1.73 & 1.42 & $.023 *$ \\
Books & 2.60 & & \\
Credit card ownership and attitude towards credit card & 1.74 & .082 \\
Number of credit cards owned & 2.18 & 2.81 & .323 \\
Frequency of usage & 2.68 & 1.88 & .094 \\
Monthly credit card expense & 2.35 & 1.93 & .855 \\
Tendency to revolve & 1.90 & 1.94 & .113 \\
Missed payments & 2.23 & .386 \\
Attitude towards credit card & & & \\
\hline \hline Sign & & & \\
\hline
\end{tabular}

*Significant at $p<0.05$

The current study found that the income level of respondents was not influential in credit card ownership and in the attitude towards debt. These results are consistent with the findings of Choi and DeVaney (1995). While several studies showed that income level is influential, these studies are not consistent in the direction of its influence. In the study from 
the USA, lower income families used credit cards more frequently than families of higher income (Danes \& Hira, 1990).

In the study from Singapore, credit cards can provide lower income households a line of credit that is easier to access than other potential sources of credit (Sharpe et al., 2012). However, several studies from different countries suggest that card ownership is positively related to income (Themba \& Tumedi, 2012; Abdul-Muhmin \& Umar, 2007; Kaynak \& Harcar, 2001; Chan, 1997; Heck, 1987; Adcock et al., 1977). Some studies specifically found that higher level of annual income is associated with a greater number of credit cards (Kinsey, 1981; Wasberg et al., 1992; Gan et al., 2008; Wang et al., 2011). On the tendency to revolve, the study from Botswana (Themba \& Tumedi, 2012) showed that the high-income group had the tendency to revolve than the low-income group, but the study from Saudi Arabia (Abdul-Muhmin \& Umar, 2007 and India (Khare et al., 2012) showed otherwise.

Correlational analysis revealed that the credit cardholders with a positive attitude towards credit cards used their cards more often and purchased more using credit cards as it showed a strong correlation in Table 9. The finding affirms the study from USA (Joo et al., 2003) except that in this study, positive attitude towards credit cards does not lead to an increased number of credit cards being owned. Local cardholders may not have seen the need for more than one credit card as having one is already sufficient for their credit needs. Cardholders with a positive attitude towards credit cards use credit card more often and spend more using it than those with a negative attitude towards debt. It means that those cardholders who do not like using credit cards tend to be more cautious of their credit activities. The number of credit cards owned is positively correlated with the frequency of usage and with monthly credit card expenses. These findings are consistent with literature from Malaysia, Saudi Arabia and Singapore (Ramayah et al., 2002; Abdul-Muhmin \& Umar, 2007; Gan et al., 2008).

The current study also showed that the more the cardholders used their credit cards, the higher the possibility of missing payment on time or defaulting on payment. Further, those who missed paying on time are usually the revolvers. Missing payments on time and revolving are both risky activities since they entail high credit expense due to penalties and interest charges. 
Table 9. Correlation between attitude towards credit card and credit card ownership.

\begin{tabular}{|c|c|c|c|c|c|c|c|}
\hline & & Attitude & $\begin{array}{l}\text { No. of } \\
\text { credit } \\
\text { cards } \\
\text { owned }\end{array}$ & $\begin{array}{c}\text { Frequency } \\
\text { of usage }\end{array}$ & $\begin{array}{l}\text { Monthly } \\
\text { credit } \\
\text { card } \\
\text { expenses }\end{array}$ & $\begin{array}{l}\text { Tendency } \\
\text { to revolve }\end{array}$ & $\begin{array}{c}\text { Missed } \\
\text { payments }\end{array}$ \\
\hline \multirow[t]{2}{*}{ Attitude } & $\begin{array}{l}\text { Pearson } \\
\text { Correlation }\end{array}$ & 1 & -.095 & $.248 * *$ & $.276^{* *}$ & -.068 & -.010 \\
\hline & $\begin{array}{l}\text { Sig. (two- } \\
\text { tailed) }\end{array}$ & & .164 & .000 & .000 & .322 & .889 \\
\hline \multirow{2}{*}{$\begin{array}{l}\text { Number } \\
\text { of credit } \\
\text { cards } \\
\text { owned }\end{array}$} & $\begin{array}{l}\text { Pearson } \\
\text { Correlation }\end{array}$ & -.095 & 1 & $.146^{*}$ & $.139 *$ & -.131 & -.071 \\
\hline & $\begin{array}{l}\text { Sig. (two- } \\
\text { tailed) }\end{array}$ & .164 & & .033 & .042 & .055 & .301 \\
\hline \multirow[t]{2}{*}{$\begin{array}{l}\text { Frequency } \\
\text { of usage }\end{array}$} & $\begin{array}{l}\text { Pearson } \\
\text { Correlation }\end{array}$ & $.248 * *$ & $.146^{*}$ & 1 & $.466^{* *}$ & .047 & $.241 * *$ \\
\hline & $\begin{array}{l}\text { Sig. (two- } \\
\text { tailed) }\end{array}$ & .000 & .033 & & .000 & .491 & .000 \\
\hline \multirow{2}{*}{$\begin{array}{l}\text { Monthly } \\
\text { credit card } \\
\text { expenses }\end{array}$} & $\begin{array}{l}\text { Pearson } \\
\text { Correlation }\end{array}$ & $.276^{* *}$ & $.139 *$ & $.466^{* *}$ & 1 & -.060 & $.251 * *$ \\
\hline & $\begin{array}{l}\text { Sig. (two- } \\
\text { tailed) }\end{array}$ & .000 & .042 & .000 & & .383 & .000 \\
\hline \multirow[t]{2}{*}{$\begin{array}{l}\text { Tendency } \\
\text { to revolve }\end{array}$} & $\begin{array}{l}\text { Pearson } \\
\text { Correlation }\end{array}$ & -.068 & -.131 & .047 & -.060 & 1 & $.338 * *$ \\
\hline & $\begin{array}{l}\text { Sig. (two- } \\
\text { tailed) }\end{array}$ & .322 & .055 & .491 & .383 & & .000 \\
\hline \multirow[t]{2}{*}{$\begin{array}{l}\text { Missed } \\
\text { payments }\end{array}$} & $\begin{array}{l}\text { Pearson } \\
\text { Correlation }\end{array}$ & -.010 & -.071 & $.241 * *$ & $.251 * *$ & $.338 * *$ & 1 \\
\hline & $\begin{array}{l}\text { Sig. (two- } \\
\text { tailed) }\end{array}$ & .889 & .301 & .000 & .000 & .000 & \\
\hline
\end{tabular}

** Correlation is significant at the 0.01 level (2-tailed).

* Correlation is significant at the 0.05 level (2-tailed).

In this study, credit card usage patterns that determine risky activities are revealed. The more credit cards owned, the higher the tendency of the cardholders to revolve, to miss on-time payments, and to spend more. The information generated from this study will provide understanding on the risky tendencies among credit cardholders in Ozamiz City and will provide insights on how to improve their personal financial management. The results of this study may be beneficial to the booming financial industry in the area through formulation of better credit card 
policy by the issuing banks, thereby preventing the emergence of a credit bubble.

\section{Conclusions and Recommendations}

The credit card usage pattern varies in relation to the socioeconomic status of the respondents. Age, marital status and educational attainment significantly influence the type of spending and credit card ownership. High credit card expense is highly correlated with the positive attitude of cardholders towards debt. The more credit cards owned, the higher the tendency of the cardholders to revolve, to miss payments on time, and to spend more. The risky credit card practices revealed in this study can further contribute to the high credit defaults in the Philippines. This phenomenon is becoming a big problem even in highly developed countries.

It is important for the government to tighten its regulation on the banking sector with regard to its credit card issuances as high payment defaults could threaten the country's financial stability. Strengthening the credit card literacy program for cardholders may greatly decrease the problem on high payment defaults. Researchers may also take part by conducting further studies to enhance understanding on consumers' credit card usage thereby enabling them to make plausible recommendations on managing consumer spending using credit cards.

\section{Acknowledgment}

The author is grateful to Misamis University for funding this study, the faculty and staff of the College of Business and Management for their support, and to the Misamis University Research Center for their guidance. 


\section{Literature Cited}

Abdul-Muhmin, A. G., \& Umar, Y. A. (2007). Credit card ownership and usage behaviour in Saudi Arabia: The impact of demographics and attitudes toward debt. Journal of Financial Services Marketing, 12(3), 219-234.

Adcock Jr, W. O., Hirschman, E. C., \& Goldstucker, J. L. (1977). Bank credit card users: An updated profile. Advances in Consumer Research, 4(1), 236-241.

Arora, R. (1987). Consumer knowledge of finance charges on credit card purchases. Development in Marketing Science, 10, 15-18.

Banko Sentral ng Pilipinas. (2014a). "Banking Statistics - Universal and Commercial Banking System”, archived 2012-2013. Retrieved from: http://www.bsp.gov.ph/banking/bspsup_universal. asp

Banko Sentral ng Pilipinas. (2014b). "Status Report on the Philippine Financial System", archived 2013. Retrieved from: http://www.bsp.gov.ph/downloads/Publications/2013/Stat Rep_ 2Sem2013b.pdf

Barker, T., \& Sekerkaya, A. (1992). Globalization of credit card usage: The case of a developing economy. International Journal of Bank Marketing, 10(6), 27-31. doi: http://dx.doi.org/10.1108/0265232 9210017299

Borden, L. M., Lee, S. A., Serido, J., \& Collins, D. (2008). Changing college students' financial knowledge, attitudes, and behavior through seminar participation. Journal of Family and Economic Issues, 29(1), 23-40. doi: 10.1007/s10834-007-9087-2

Canner, G. B., Luckett, C. A., Cook, W. C., \& Peirce, M. A. (1992). Developments in the pricing of credit card services. Federal Reserve Bulletin, 78, 652. 
Cayanan, A. S., \& Ledesma, C. C. (2005). An analysis of the credit card industry in the Philippines. In R. A. Rodriguez \& M. B. Albarracin (Eds.), Analysis of selected Philippine industries: Volume I (pp. 177 - 229). Quezon City, Philippines: The University of the Philippines Press.

Chan, R. Y. K. (1997). Demographic and attitudinal differences between active and inactive credit cardholders - The case of Hong Kong. International Journal of Bank Marketing, 15(4), 117-125. doi: http://dx.doi.org/10.1108/02652329710189375

Chien, Y. W., \& Devaney, S. A. (2001). The effects of credit attitude and socioeconomic factors on credit card and installment debt. Journal of Consumer Affairs, 35(1), 162-179. doi: 10.1111/j.17456606.2001.tb00107.x

Choi, H. N., \& DeVaney, S. (1995). Factors associated with the use of bank and retail credit cards. In Proceedings of the Society for Consumer Psychology (pp. 152-9). La Jolla, CA: American Psychology Association.

Danes, S. M., \& Hira, T. K. (1990). Knowledge, beliefs, and practices in the use of credit cards. Home Economics Research Journal, 18(3), 223-235. doi: 10.1177/1077727 X9001800304

Davies, E., \& Lea, S. E. (1995). Student attitudes to student debt. Journal of Economic Psychology, 16(4), 663-679. doi: 10.1016/01674870(96)80014-6

Delener, N., \& Katzenstein, H. (1994). Credit card possession and other payment systems: Use patterns among Asian and Hispanic consumers. International Journal of Bank Marketing, 12(4), 13-24. doi: http://dx.doi.org/10.1108/02652329410058003

Estayo, M. (2008, April 17). Consumer credit defaults in RP triple the Asia rate. Malaya Business. 
Finke, M. S., \& Huston, S. J. (2014). Financial literacy and education. Investor Behavior: The Psychology of Financial Planning and Investing, 63-82.

Gan, L. L., Maysami, R. C., \& Koh, H. C. (2008). Singapore credit cardholders: Ownership, usage patterns, and perceptions. Journal of Services Marketing, 22(4), 267-279.

Hamilton, R., \& Khan, M. (2001). Revolving credit card holders: Who are they and how can they be identified?. Service Industries Journal, 21(3), 37-48. doi: 10.1080/714005031

Hancock, A. M., Jorgensen, B. L., \& Swanson, M. S. (2013). College students and credit card use: The role of parents, work experience, financial knowledge, and credit card attitudes. Journal of Family and Economic Issues, 34(4), 369-381. doi: 10.1007/s10834-0129338-8

Hayhoe, C. R., Leach, L. J., Turner, P. R., Bruin, M. J., \& Lawrence, F. C. (2000). Differences in spending habits and credit use of college students. Journal of Consumer Affairs, 34(1), 113-133. doi: 10.1111/j.1745-6606.2000.tb00087.x

Heck, R. K. (1987). Differences in utilisation behaviour among types of credit cards. The Service Industries Journal, 7(1), 41-64. doi: $10.1080 / 02642068700000006$

Holub, T. (2002). Credit card usage and debt among college and university students. ERIC Digest.

Johnson, P. J. (2007). Credit card practices of Vietnamese and Laotian newcomers to Canada: A 10-year longitudinal perspective. Journal of Family and Economic Issues, 28(2), 227-246. doi: 10.1007/s10834-007-9056-9 
Joo, S. H., Grable, J. E., \& Bagwell, D. C. (2003). Credit card attitudes and behaviors of college students. College Student Journal, 37(3), 405-419.

Kaynak, E., \& Harcar, T. (2001). Consumers' attitudes and intentions towards credit card usage in an advanced developing country. Journal of Financial Services Marketing, 6(1), 24-39. doi: http://dx.doi.org/10.1057/palgrave.fsm.4770038

Khare, A., Khare, A., \& Singh, S. (2012). Factors affecting credit card use in India. Asia Pacific Journal of Marketing and Logistics, 24(2), 236-256. doi: http://dx.doi.org/10.1108/ 13555851211218048

Kinsey, J. (1981). Determinants of credit card accounts: An application of Tobit analysis. Journal of Consumer Research, 8(2), 172-182.

Lee, J., \& Kwon, K. N. (2002). Consumers' use of credit cards: Store credit card usage as an alternative payment and financing medium. Journal of Consumer Affairs, 36(2), 239-262.

Ludlum, M., Tilker, K., Ritter, D., Cowart, T., Xu, W., \& Smith, B. C. (2012). Financial literacy and credit cards: A multi campus survey. International Journal of Business and Social Science, 3(7), 25-33.

Lyons, A. C. (2004). A profile of financially at-risk college students. Journal of Consumer Affairs, 38(1), 56-80. doi: 10.1111/j.17456606.2004.tb00465.x

Nolan, S. A., \& Heinzen, T. E. (2010). Essentials of statistics for the behavioral sciences. New York: Worth Publishers.

Norvilitis, J. M., \& Santa Maria, P. (2002). Credit card debt on college campuses: Causes, consequences and solutions. College Student Journal, 36(3), 357-364. 
Ramayah, T., Noor, N., Nasurdin, A. M., \& Choo, L. H. (2002). Cardholder's attitude and bank credit card usage in Malaysia: An exploratory study. Asian Academy of Management Journal, 7(1), 75-102.

Robb, C. A. (2011). Financial knowledge and credit card behavior of college students. Journal of Family and Economic Issues, 32(4), 690-698. doi: 10.1007/s10834-011-9259-y

Roberts, J. A., \& Jones, E. (2001). Money attitudes, credit card use, and compulsive buying among American college students. Journal of Consumer Affairs, 35(2), 213-240. doi: 10.1111/j.17456606.2001.tb00111.x

Sharpe, D. L., Yao, R., \& Liao, L. (2012). Correlates of credit card adoption in urban China. Journal of Family and Economic Issues, 33(2), 156-166. doi: 10.1007/s10834-012-9309-0

Tan, W. L. (2009). Consumer credit in the Philippines. Bank for International Settlements Communications CH 4002 Basel, Switzerland, 117.

Themba, G., \& Tumedi, C. B. (2012). Credit card ownership and usage behaviour in Botswana. International Journal of Business Administration, 3(6), 60-71. doi: 10.5430/ijba.v3n6p60

Wang, L., Lu, W., \& Malhotra, N. K. (2011). Demographics, attitude, personality and credit card features correlate with credit card debt: A view from China. Journal of Economic Psychology, 32(1), 179193. doi:10.1016/j.joep.2010.11.006

Wasberg, C. A., Hira, T. K., \& Fanslow, A. M. (1992). Credit card usage and consumer debt burden of households. Journal of Consumer Studies \& Home Economics, 16(1), 19-32. doi: 10.1111/j.14706431.1992.tb00496.x 
Wickramasinghe, V., \& Gurugamage, A. (2009). Consumer credit card ownership and usage practices: Empirical evidence from Sri Lanka. International Journal of Consumer Studies, 33(4), 436-447.

Xiao, J. J., Noring, F. E., \& Anderson, J. G. (1995). College students' attitudes towards credit cards. Journal of Consumer Studies \& Home Economics, 19(2), 155-174. doi: 10.1111/j.1470-6431.1995. tb00540.x

Zikmund, W. G. (2003). Exploring marketing research $\left(8^{\text {th }}\right.$ ed.). Ohio, USA: Thomson South-Western Mason. 